\title{
Amalgamation in Rural Communities: Case Study for the Integration of Various Local Subculture Identities in Rural Java
}

\author{
Tadjoer Ridjal $^{1} \quad$ Humaidah Muafiqie $^{2} \quad$ Suko Susilo $^{3} \quad$ Tri Susilowati ${ }^{4}$ \\ 1.Departement of Sociology, University of Darul 'Ulum Jombang, Indonesia \\ 2. Departement of Economics, University of Darul 'Ulum Jombang, Indonesia \\ 3.Departement of Da'wah, Islamic Institute of Tribakti Kediri, Indonesia \\ 4. Departement of Law, University of Darul 'Ulum Jombang, Indonesia
}

\begin{abstract}
This study follows up the previous studies conducted at the same location. The society structure developed in this village did not much different from the structure of Javanese villages in general, generally under the joint influence of Islam and the colonial. This village community developed into three family groups or local subcultural identity groups. The three groups are wong njero, wong njaba and wong mambu-mambu. Although it consists of various groups, but social life in this village is very harmonious. Therefore, the question of this study is: How do rural communities solve the various construction problems of locality subcultural identities in their daily lives? This study uses a qualitative approach to explore the meaning behind reality. The data collection process involves informants. They help to collect and clarifying field data or for cross checking field data. Data is analysed by flow models. The results showed that the amalgamation were originated from the marriage between one members of Wong Njero family and Wong Njaba, and minimizing the differences in background of local subculture.
\end{abstract}

Keywords: Local Subculture, Rural Java, Amalgamation

DOI: $10.7176 /$ RHSS/10-14-08

Publication date:July $31^{\text {st }} 2020$

\section{Introduction}

This study follows the study of Ridjal (2004-a) and Ridjal et al. (2019) at a village in Jombang District, East Java, where almost all of the citizens were Muslim. The village is located $20 \mathrm{~km}$ southeast of district capital, and $7 \mathrm{~km}$ northeast of subdistrict capital. Like most rural areas, most of the village community work in agricultural sector. The lifestyle of farming community is more colouring the life of village. The characteristics of a stratified agrarian society (Sanderson, 1995) also appear in this village.

In terms of control of agricultural land, most of them are farm workers who do not have rice fields. Norldholt (1987) and $\mathrm{Li}$ (2002) stated that most of them belong to magersaren type, while Breman (1986) uses the term "menumpang" ("hitchhiking"). In line with socio-economic conditions of village community, when the JPS (Social Safety Net) program was first initiated, number of poor families receiving IDT assistance was large. In fact, many of community members receive "goats grant" in Social Safety Net program. This village is the most compared to other villages in the sub-district area. Most of their jobs are farm labourers (Ridjal, 2004-a). In addition to farming, other types of work are carpenters and masons, rickshaw pullers, factory workers, and ngemblek (taking teak wood in forest), as well as some household assistant.

The community structure developed in this village does not much different from structure of Javanese villages in general (Ridjal, 2004-a). Geertz (1981) stated that structure of Javanese village society was under the joint influence of Islam and colonial. Geertz (1960) examined the cultural value system and classifying Javanese people into santri, priyayi, and abangan. This classification come into three cultural variants, according to Legge (in Muchtarom, 1988), it poses the danger of disrupting different categories, due to fact that there are santri-priyayi or abangan-priyayi. Therefore, McVey (1970) asserts that Javanese society is actually divided into two parts of culture, namely the santri identity group and abangan identity group.

Based on cultural system of "Javanese religion" values, Ridjal (2004-a) stated that structure developed in this village seemed to follow McVey's view. According to a number of villagers, village community consisted of gendera ijo (green flag or santri) and gendera abang (red flag or abangan). Such classification is consistent with kirata for name of Jombang region - an acronym from Ijo and Abang. Ridjal (2004-b) said that kirata is an abbreviation of word kira-kira ning nyata (approximation but real). It is a word to make strategy to achieve a meaning that is "deemed appropriate", which in Javanese means cocog (Geertz, 1993). This kirata term was also reviewed by Kholil (2009), Parsudi Suparlan (2006) and Tiani (2018).

The village community developed into three groups. Ridjal (2004-a) termed the identity groups of local subculture as Wong Njero, Wong Njaba and Wong Mambu-mambu. Wong Njero is a symbol of identity for family members of village clerics. Wong Njaba is a symbol of identity to describe members of community who are politically and socially in lower strata, and most of village government officials generally come from people who 
are symbolized as Wong Mambu-mambu. Based on the kinship, members of Wong Mambu-mambu group consider themselves to still have a kinship with Wong Njero. Whereas those who come from Wong Njaba group consider themselves not have a direct kinship with other two groups, especially with Wong Njaba. Based on thoughts derived from above background, question in this study is: How do rural communities solve the various construction problems of locality subculture identities in their daily lives?

\section{Thinking Framework and Methodology}

Values that closely related to culture are also closely related to patterns of social relations. The relationship between cultural values (cultural bias) and patterns of social relations (social relations) becomes mutual relationships (compatibility conditions) (Thompson et al., 1990). Haddad et al (2019) stated that a cultural bias is a tendency to interpret a word or action in according to cultural defines it.

The relationship between the two components - cultural bias and social relations is manifested in a way of life (typology of their sociality). Harris (1969) views human way of life as a pattern of behavior that is bound to certain groups that originate from culture. In other words, reality of typology of community sociality is a manifestation of values that are believed and developed by individuals as members, and vice versa. In this regard, Thompson et al (1990) use the concept of nature myth of certain value believed and developed by community members. The myth of nature has also been reviewed by Slattery (2005). Adisubroto (1996) also concluded that values are beliefs of attitude standard that relatively consistent with their actions or behaviour.

The orientation of individual values as society members is the disposition of actions value formed from his life experiences. Individual life experiences as members of community are a series of activities where they follow the traditions or rhythms of their daily lives. The tradition describes a particular cultural taste (Wright, 2015) that depends on context to show the interrelationship between the orientation of individual values as society members and social conditions where they live.

Community life in a certain locality transmits a dominant culture internalized in individual member's lives. The internalized culture is not easy to be eliminated just like that by a new culture transmitted at a later stage, but it allows for integration of various alternative cultures. In addition, social interaction allows dialogical process to define subculture identities between localities. Therefore, dominant culture that lives in community is a blend of alternative cultures transmitted at each stage of development of the community concerned and crossover (Jaqueline Berndt, 2011) between localities.

This study uses a qualitative approach, following the views of Yin (2011), Tracy (2013) and Miles et al, (2014), with aims to explore and building a proposition or explain meaning behind reality (Ridjal, 2003). Researchers stand from reality that occurs in field, namely the life of a tradition that was originally considered homogeneous or seen to follow the rhythm of daily life that lives in certain circles. The rhythm of daily life seems to have been seen as the identity of local subcultures of individuals as society members as a whole that illustrates the orientation of values in their social life. This study explores the social world of everyday life.

This study explores the events in world to attach the findings obtained in it. Therefore, the field work is included in a position based on case, ideographic, and emic, which directs attention to specifics cases. The meaning of social phenomena - through the method of self-intersubjectives - is emphasized, but the objective conditions of socio-cultural life are not ruled out (Ridjal, 2003).

The focus of attention in this study is on daily cultural life. Based on this focus of attention, the study area emphasizes on the cultural traditions that live in community. Cultural traditions are the basis for data collection. Furthermore, this study also considers Anderson's (1991) statement that nature and extent of community are largely a matter of individual definition. Therefore, data collection was representatives of these study units to emphasize on the procedure to implement tradition, values that underlie it and more importantly, understanding or meaning of individuals as society members towards tradition.

Many informants were involved in this data collection. They not only help in collecting data, but also clarifying field data or cross checking of field data. The collected data is interpreted by considering the informants' understanding. There are some differences in interpretation of data about the same event. This situation needs clarification involving more informants, including informants who live outside the study location village. This step emphasizes the application of consistency techniques and field data congruence. Lincoln and Guba (1985) and Merriam (1995) explored the congruence for internal validity, and consistency or dependability for reliability of qualitative study data.

The data collection results are directed to achieve a high level of consistency and congruence based on the direction of Adler and Adler (1994), namely using a "double observer" strategy, conducting data relevance tests through peer discussions and seminars, using various data collection techniques from various source and involved in situation of study location. Data analysis takes place simultaneously with data collection process or through the stages of flow model from Miles and Huberman (1994), namely data collection, data reduction, data presentation, and verification that running simultaneously. 


\section{Data Disclosure and Discussion}

The legendary genealogical myth (the genealogy term borrowed from Foucault, 1980) who lived in community, the funding father of the village was Mbah Kiai Isman. He is a descendant of Prince Alif, a cleric of Majapahit era. Alif's tomb is visited by many pilgrims, especially at every Friday night. After Isman's death, village leadership was continued by his sons Hasani (religious affairs) and Abdul, who was also called Mbah Muketar (village head). In the next period, village leadership was held by Hasani's two sons, Nurman (religious sector) and Maskur (village head), and subsequently these two fields were controlled by Nurman's second son, Bari take a role since 1946 until he resigned due to old age in 1989. Since 1990 the village head was occupied by one of descendants of Wong Mambu-mambu family through the election of a single candidate. The village clerics remain under the control of members of Wong Njero hereditary generation.

The Isman leadership has two other groups in community who did not have kinship on basis of their descendants. They are kadam (Kiai servants) and migrants who are generally as farm labourers. The term kadam is similar to what was stated in study of Ma'rifatun (2016), namely khodam. The kadam occupy the waqf land close to neighbourhood of Isman family. While the settlers lived at northern end of village and this location have been a gift from Isman. Prominent characteristics to distinguish the three circles (Isman family, kadam, and migrants) are mastery of agricultural land, formal education, and especially mastery of religious knowledge. The villagers story showed the Hasani gave a yard of approximately $4000 \mathrm{~m} 2$ to a loyal kadam named Mukasip to be used by his descendants, but with condition that: (1) may not be sold, and (2) must not be inherited. The interesting thing about this plot is about the number of houses, which is never more than four. One new house was built, always followed by another old house abandoned.

The social and religious life in this village has greatly improved during the leadership of Nurman and Maskur. They established boarding schools, restored mosques, and built family burial sites behind the mosque. This village has been known by residents of surrounding villages as santri village (a symbol of observance of worship in Islam) or religious kedhung, a local term meaning as a Center for teaching and learning activities in Islamic religion, or pesantren (Ridjal et al., 2019). The change in designation of village's identity, in turn, encourages efforts to separate families. Time began to advance the terms associated with family background, namely Wong Njero, Wong Njaba and Wong Mambu-mambu (Ridjal, 2004-a).

Wong Njero is a symbol of identity that is propped up against those who are members of Hasani family who have never been married to Wong Njaba. These circles are believed to have advantages in terms of mastering religious knowledge and a higher level of formal education than other circles. In addition, Wong Njero is also symbolized as a controlling model of social, religious and moral life. Therefore, every religious social activity such as recitation and various other slametan (alms) always led by representatives from this circle, or at least lead the prayer. In addition, those who come from this circle also receive special treatment in daily interactions with other members of community, especially with Wong Njaba. This can be observed from their nickname which is always given an additional subasita (call of respect) article. Their honour names seem tiered. For men consists of Mbah Kiai, Kiai and Gus; while for women it consists of Mbah Ibu Nyai, Mbah Ning and Ning. With regard to such vocations, they generally feel that they are members of civilized family groups. The designation of santri village or religion kedhung is seen as a reflection of way of life among their people. Although it is not exactly the same, it is likely that this has something in common with opinion of Elias (1988) regarding the process of civilization that originated from code of conduct in Europe.

Wong Njero is symbolized as a model to controls the social life behaviour of community. It has a similarity from Mennel's analysis of Elias's theory of civilization. Mennel (in Waters, 1994) said that people who experience the process of empowerment was specialists who become models and controllers of social behaviour. However, in their development sometimes they act the opposite. This has happened in this village around the 1970s, when a member of Wong Njero punished a child from Wong Njaba who stole cassava by straying, ie torturing with bites of hundreds of large red ants. According to convict's confession from Wong Njero, such actions were carried out to educate children to adhere to morals in accordance with designation of their village, namely the santri village or religious kedhung. That sort of thing seems to be in line with statement of Evers (1988) that process of civilization produces dialectical outrage. In other words, barbaric acts were carried out by people who consider themselves civilized.

Wong Mambu-mambu is a symbol of identity for group members who consider them to have a kinship with Wong Njero. However, they also consider having a kinship with Wong Njaba. The kinship with other two groups is said to have originated from a marriage between one of Isman's sons with Wong Njaba. However, at that time the Wong Njaba term had not yet come to fore. At that time, Wong Njaba community was still known as Wong Loran, a local term to define people who lived in northern end of village. As described above, during the Isman era, people who lived in far north of village were mostly migrants who generally worked as farm labourers.

This cultural amalgamation can bridges the differences between the two family groups. The individuals who are believed to come from among the Wong Mambu-mambu are ultimately treated differently by members of Wong Njero, rather than their treatment of Wong Njaba. For example, activities of dibaan (the ritual to read blessings in 
book of diba), management authority is given to adolescents who are believed to have offspring from poor people. Apparently, marriage can break the legitimacy of authority to control the practices of social and religious ritual ceremonies which at first were always dominated by Wong Njero. Therefore, residents from community of Wong Njaba give names to individual members of community of Wong Mambu-mambu as Bala Njero, which means there is still a kinship with Wong Njero. This is consistent with Bagong Sujanto and Dwi Narwoko (2006) statement that amalgamation is also one solutions to eliminate various disputes within a community group.

Most members of Wong Njaba circle do not have a direct kinship with two groups mentioned above, especially with Wong Njero. Most of them consist of poor families as "menumpang" (Breman, 1987) or magersaren (Norldholt, 1987 and Li, 2002). Their religious knowledge and formal education are relatively lower than the members of other two circles. They are considered not part of santri village, so they are also called Wong kedhusan, it is a symbol of identity to characterize people who commit many sins, or act like wedhus (goats). In fact, most villagers believe that many children from Wong Njaba community were born from ramban in past, a local term that likens it to behaviour of goats that eat grass or leaves in any place. They are often viewed by Wong Njero as people who easily commit immorality, namely violating religious restrictions regarding the issue of social relations. They are members of community who dominate in terms of number of people who are physically involved in mutual cooperation activities, although lately they have often been mbanggel, or refuse orders. Lichbach (1994) said that such actions are one type of farmer-style resistance. Scott (1985) termed their actions as Everyday forms of Resistance.

The Wong Njero controls around 45\% village agricultural land. They are better economically than other members of community. Wong mambu-mambu controls almost $35 \%$, and rest is controlled by Wong Njaba community. In fact, most family members from Wong Njaba group belong to "passenger" or permanent magersaren type. Members of this third circle seem to have only received a portion of land since the Isman era, and it has never been transfer the land ownership from other two groups to people from among those who had this symbol of identity, while this study conducted.

The individuals as society members have different socio-cultural identity backgrounds between group members and other group members. The symbol of cultural identity seems to have originated santri village or religious kedhung. Before that time the villagers were only divided into wong loran and wong kidulan. Wong Loran is people who live in northern part of village, and Wong Kidulan is those who live in southern part of village. Santrinisasi becomes determination the orientation of dominant cultural values in everyday life. Those who act deviate from dominant culture are seen as not part of Sumberarum residents who are santri, so they are called Wong Njaba. In fact, Wong Njaba is derogated as wong kedhusan.

In the reality of daily life, these differences are manifested through designations to indicate from which group the individual comes from. As mentioned above, there are three kinds of identity symbols namely Wong Njaba, Wong Njero and Wong Mambu-mambu. Individuals as members of each group show different rhythms of daily life, especially religious ritual traditions. However, in its development these differences have changed, or become increasingly blurred. The reality shows a blurring differences in classification of group identity related to characteristics of tradition or the rhythm of their everyday cultural symbolism. The grouping is based on background of locality culture identity which in past is very prominent. In the Wong Njaba community, Pak Wak was appeared to do socio-religious tasks that were previously only carried out Wong Njero, especially in leading religious rituals. Pak Wak leads the social religious rituals such as tahlilan and small scale manakiban among Wong Njaba, who come from their own group. Pak Wak was appointed personally by Wong Njaba through the mechanism to show to its members who have suitable criteria: can read and teach the Qur'an in their circles, and often became the prayer leader at langgar (small mosque). Pak Wak leader can reduce the cost of slametan (alms) that is a communal party or festivity in commemoration of something or as an expression of gratitude. This communal party tradition can be done with a model of bancakan (slametan that only invites a few neighbours around the house) or purakan (eat together in a slametan, ie 4-6 people swarm a container of food that is presented to be eaten together). Regarding slametan, Clifford Geertz (1960) regarded it as a core ritual in Javanese religion, especially the abangan variant. Furthermore, this slametan tradition has been reviewed by Kholil (2009). The bancakan was examined in detail by Ed-Dally (2019) and pretext was also revealed by Khotimah (2019).

Pak Wak does the task from kyai who in past always came from Wong Njero circles. In the past, violating the authority (a sacred rule) was considered as nyulayani adat (deviating from tradition). In line with these changes, identity symbols both before and after the village became a religious discipline, are no longer in forefront. Society seems construct a new identity to binds the diversity of traditional particularistic identities that ever developed. They named this new identity construction with padha tampare. However, this new identity has emerged along with santrinisasi journey in this village.

It seems that Wong Njero, symbolized as a controlling model of dominant culture in religious affairs, tends to subordinate the cultural life of community members who are seen as not manifesting the identity of dominant culture. This dominant group tends to subordinate the cultural life of other "competitors" among those who are seen as deviating from culture to control of religious affiliation through the symbolization of derogative identity 
as wong kedhusan. Under these conditions, socialization or enculturation in daily life is sought in order to establish cultural homogenisation. However, at same time community members develop their own way to interpret cultural homogenization based on their traditional cultural life.

\section{Conclusions}

The socialization or enculturation process makes dominant group tend to deculturate or substitute the cultural life of society members - in social stratification system that lives in the society - the social position below. However, enculturation of interaction process between locality subculture identities allows the dialogue between their respective value orientations. Such conditions enable individuals as members of community to know each other's cultural identity in their daily lives. In turn, differences manifestations of cultural identity in traditions that previously followed the vertical classification of locality subculture identities will lead to diversity in transverse positions or horizontal categorization. This position makes the dominant culture is transmitted in daily life by dominant group without alienate or marginalize the cultural life of others, but allows for integration and diversification. Individuals as members of community develop their own meanings based on their own value orientation towards the dominant culture in their daily lives.

Cultural life in the village seems to indicate a diversity of traditions or the daily life rhythm of individuals as members of community that were initially ignored. This village has been known for a long time by people from surrounding villages as a santri village or religious kedhung. It turns out to be only a symbol of identity that manifests one side of rhythm of daily lives of people from certain circles, so that rhythm of daily lives of people from among others are deliberately not brought to surface. The identity symbol indicates the dominance of rhythm of daily life manifested in traditions that live in certain circles. The rhythm of life of dominant group has been seen as representing the characteristics of village communities. The identity symbol seems to be associated with establishment of pesantren as a symbol of santri identity. In fact, the daily life of student's rhythm that is manifested in tradition behaviour of "social religious" of individual society members as a whole is varied. However, amalgamation through marriage between members of Wong Njero family and Wong Njaba can minimize the differences in identity background of local subculture.

\section{REFERENCES}

Adisubroto, 1996, "Orientasi Nilai Orang-orang Daerah Pegunungan, Dataran Rendah dan Pantai Utara Jawa Tengah", Jurnal Psikologi, (2): 40-54.

Adler, PA and P Adler, 1994, "Observational Techniques", in NK Denzin and YS Lincoln (ed), Handbook of Qualitative Research, London: Sage Publications, pp. 377-391.

Anderson, B, 1991, "Gagasan Tentang Kekuasaan Dalam Kebudayaan Jawa”, dalam M Budiardjo (ed), Aneka Pemikiran Tentang Kuasa dan Wibawa, Jakarta: Pustaka Sinar Harapan, pp. 44-125.

Berndt, Jaqueline, 2011, Intercultural Crossovers, Transcultural Flows: Manga/comics: Volume 2; Kyoto Seika University: International Manga Research Center

Breman, J, 1986. "Control of Land and Labour in Colonial Java: a Case of Agrarian Crisis and Reform in the Region of Cirebon During the First Decade of the 20th Century", JPS, 12 (4): 89-92.

Ed-Dally, M Zein; 2019, "Makanan Tumpeng Dalam Tradisi Bancakan: Studi Gastronomi Pada Masyarakat Jawa Islam”, Skripsi; Surabaya: UIN Sunan Ampel

Elias, N, 1988. "Kerangka Untuk Sebuah Teori Peradaban”, dalam HD Evers (ed). Teori Masyarakat: Proses Peradaban Dalam Sistem Dunia Modern, Terjemahan, Jakarta: Obor, hal 3-24.

Evers, HD; 1988. "Proses Peradaban: Ragam Pola Dunia Atau Sistem Dunia", dalam (ed), Teori Masyarakat: Proses Peradaban Dalam Sistem Dunia Modern, Terjemahan, Jakarta: Obor, hal 25-31.

Foucault, M; 1980, Power/ Knowledge: Selected Interviews and Other Writings 1972-1977: The Harvester Press Geertz, C dan H Geertz, 1981. Aneka Budaya dan Komunitas di Indonesia, Jakarta: FIS-UI.

Geertz, C, 1960. The Religion of Java, Glencoe, III: The Free Press of Glencoe.

Geertz, C; 1993, The Interpretation of Cultures, Hammersmith, London: Fontana Press.

Haddad, Amy and Regina Doherty, Ruth Purtilo; 2019, "Respect in a Diverse Society", Health Professional and Patient Interaction, Ninth Edition, Elsevier Inc. All

Harris, M., 1969, Monistic Determinism: Anti Service. Southwestern Journal Anthropology, 25. 2: $198-206$.

Kholil, A, 2009, "Agama dan Ritual Slametan: Deskripsi-Antropologis Keberagamaan Masyarakat Jawa", elHarakah, Vol. 11, No.1: 84-98.

Khotimah, K.; 2019, Studi Ritual Undhuh-undhuh di Gereja Jawi Wetan (GKJW) Mojowarno Jombang Dalam Perspektif Talcot Parsons, Skripsi; Surabaya: UIN Sunan Ampel.

Li, Tania Murray, 2002, Proses Transformasi Daerah Pedalaman di Indonesia (terjemahan), Jakarta: Yayasan Obor Indonesia.

Lichbach, MI, April 1994, "What Makes Rational Peasants Revolutionarity?: Dilemma, Paradox and Irony in Peasant Collective Action”, World Politics, 46 (3): 383-418. 
Lincoln, YS, and EG Guba, 1985, Naturalistic Inquiry, Beverly Hills, CA: SAGE.

Ma'rifatun, N; 2016, "Metabudaya Relasi Khodam dan Kyai : Studi Kasus di Pondok Pesantren Al Falah Ploso Mojo Kediri”, Tesis, Surabaya: UIN Sunan Ampel

McVey, RT, 1970, Nationalism, Islam and Marxistm: The Management of Ideological Conflict, Ithaca, NY: Cornell University.

Merriam, S. B., 1995; What can you tell from an $\mathrm{N}$ of 1 ? Issues of validity and reliability in qualitative research. PAACE Journal of Lifelong Learning, 4: 51-60.

Miles, MB, and AM Hubermann, 1994, "Data Management and Analysis Methods", in NK Denzin and YS Lincoln (ed), Handbook of Qualitative Research, London: Sage Publications, pp. 428-443.

Miles, Matthew B. and A. Michael Huberman, Johnny Saldana, 2014, Qualitative Data Analysis: A Methods Sourcebook and The Coding Manual for Qualitative Researchers; Thousand Oaks, CA: SAGE

Nordholt, NS, 1987. “Ojo Dumeh: Kepemimpinan Lokal Dalam Pembangunan Pedesaan”. Disertasi, Jakarta: Sinar Harapan.

Ridjal, Tadjoer. 2003. "Metode Bricolage Dalam Penelitian Sosial”, Dalam Burhan Bungin (editor), Metode Penelitian Kualitatif, Aktualisasi Metodologis ke Arah Ragam Varian Kontemporer, Cetakan Kedua, Jakarta: PT RajaGrafindo Persada, Jakarta, hal. 82-100.

Ridjal, Tadjoer, 2004-a, Tamparisasi Tradisi Santri Pedesaan Jawa: Studi kasus interpenetrasi identitas Wong njaba, Wong njero dan Wong mambu-mambu, Surabaya: Kampusina

Ridjal, Tadjoer, 2004-b, Terkoyaknya Sebuah Mitos Di Balik Tumbangnya Sang Presiden: Sebuah Analisis MOAG Masyarakat Pinggiran Jawa Pedesaan, Surabaya: Kampusina.

Ridjal, Tadjoer and Suharnan, Effy Indriati, Suko Susilo, 2019; Santrinization and Egalitarian Spirit: A Case Study of Santri Village Community in Jombang, Indonesia, Historical Research Letter, Vol. 48: 29-36.

Sanderson, SK, 1995. Sosiologi Makro: Sebuah Pendekatan Terhadap Realitas Sosial, Edisi II, Jakarta: Raja Grafindo Persada

Scott, JC, 1985, Weapon of the Weak: Everyday Forms of Peasant Resistance, New Haven: Yale University Press.

Slattery, Dennis P., 2005, The Myth of Nature and the Nature of Myth: Becoming Transparent to Transcendence, The International Journal of Transpersonal Studies, Volume 24 Issue 1: 29-36.

Sujanto, Bagong dan Dwi Narwoko; 2006, Sosiologi Teks Pengantar dan Terapan. Jakarta: Kencana Media Group. Suparlan, P, 2006, "Konflik Sosial dan Alternatif Pemecahannya"; Antropologi Indonesia, Vol. 30, No. 2: 138150.

Thompson, M, and R Ellis, A Wildavsky, 1990. Cultural Theory, Boulder, San Francisco: Westview Press.

Tiani, R, Feb 2018, "Kearifan Lokal Sebagai Bentuk Kontrol Sosial Masyarakat Sukolilo"; Nusa, Vol. 13 No. 1: 137-146,

Tracy, S; 2013, Qualitative Research Methods: Collecting Evidence, Crafting Analysis, Communicating Impact; Chichester, West Sussex,: A John Wiley \& Sons, Ltd., Publication

Waters, M, 1994. Modern Sociological Theory, London: SAGE.

Wright, David, 2015, Understanding Cultural Taste: Sensation, Skill and Sensibility: Palgrave Macmillan

Yin, RK, 2011; Qualitative Research from Start to Finish; New York: The Guilford Press 